\title{
ロネットワークダイナミックス研究会 (ND)
}

2009年8月3日に非線形問題 (NLP) 研究会との併催で, ネットワークダイナミックス (ND) 研究会が, 高知県四万十市ヨンデン プラザ中村において開催されました。講師として2名の先端研究者をお招きし，講演を賜りました.

·中村知道氏 (Sony CSL)「ネットワークデータの時系列解析」

·谷澤俊弘氏 (東京大学)「多極次数分布ネットワークの構造的性質について」

中村氏はある小規模ネットワークのトラヒックを解析し，相関構造を見いだすことにより，背後にある力学的性質に接近するという 興味深いお話でした，また，谷澤氏はスケールフリーネットワークにおいて，外部からノードへの選択的攻撃とノードのランダムな 故障という二つの淆威に対して頑健なネットワークの構成を構成するという最新研究内容をお話し頂きました。 両発表ともNLP, ND 参加者の興味に合致する内容であり, 活発な質疑応答を通じて大いに刺激を受け合いました，秘親会は劇場風の一風变わった居酒屋で 行われました. 参加者は地元の海の幸に舌鼓を打ちながら, 夜遅くまでネットワークに関する熱い議論を交わしているようでした.

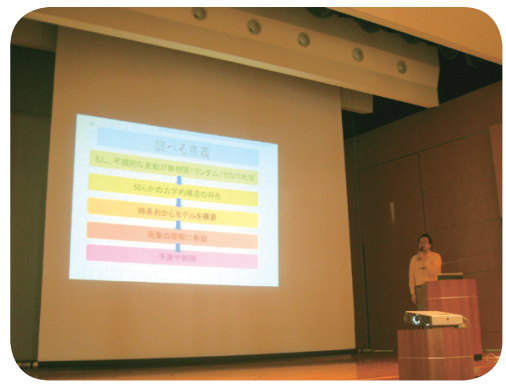

中村氏による講演

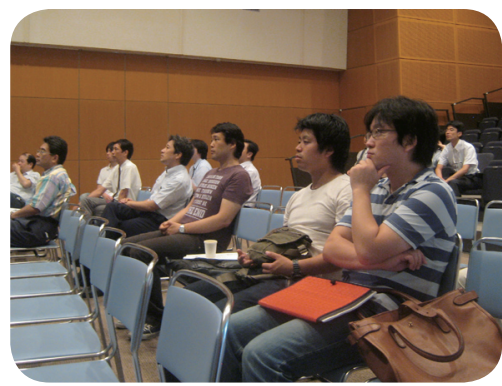

発表に食い入る聴講者

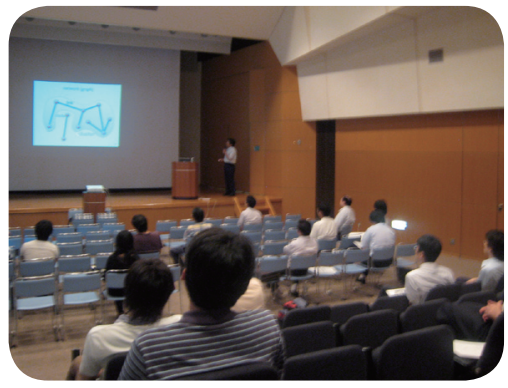

谷澤氏による講演

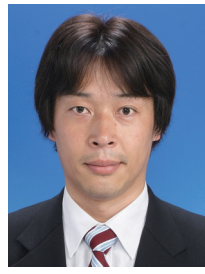

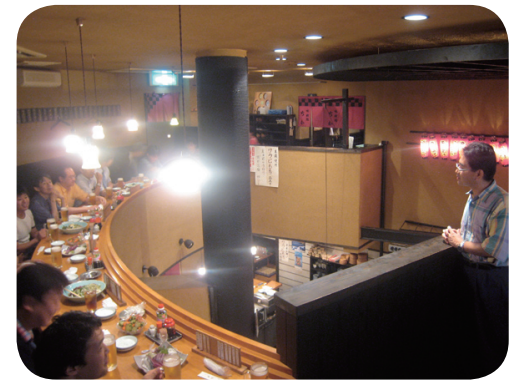

懇親会の様子

上田哲史 (正員)

平 4 徳島大大学院工学研究科博士前期課程了. 同年徳 島大·工学·知能情報・助手。現在, 徳島大高度情 報化基盤センター教授. 平21 〜ネットワークダイナ ミックス研究会副委員長. 博士 (工学). 